\title{
Peningkatan Literasi Keuangan Syariah Bagi Guru Perbankan Syariah
}

\author{
Khasan Setiaji*1, Ubaedul Mustofa², Muhammad Feriady ${ }^{3}$ \\ 1,2,3 Fakultas Ekonomi, Universitas Negeri Semarang \\ *e-mail: setiaji@mail.unnes.ac.id¹ , ubaed_almustafa@mail.unnes.ac.id²,mferiady@mail.unnes.ac.id ${ }^{3}$
}

\begin{abstract}
The sharia banking expertise program at SMK is getting developed. However, it has not been fully supported by the availability of competent teachers. That is because the teachers do not come from finance or sharia banking graduates. Having that phenomena, a sharia banking training was conducted. The partners in this activity are the MGMP Central Java and DIY Sharia Banking. The participants are 44 teachers. Before the training, a pre-test was conducted with the average score of 63.11 for each participant. After having the test, a post test was obtained with an average score of 77.07. Based on the Difference Test, it can be seen that the significance value (Sig. (2-tailed)) of 0,000 is less than 0.05. In short, it can be concluded that there are significant differences in the competence of sharia banking teachers before training and after the implementation of sharia financial training.
\end{abstract}

Keyword-sharia finance, teacher competence, sharia banking, vocational schools

\begin{abstract}
Abstrak
Program keahlian perbankan syariah di SMK terus berkembang. Namum, belum sepenuhnya didukung oleh ketersediaan guru pada kompetensi tersebut. Hal tersebut dikarenakan guru tidak berasal dari lulusan di bidang keuangan atau perbankan syariah. Fenomena tersebut yang melatarbelakangi dilakukannya pengabdian ini. Mitra kegiatan ini adalah MGMP Perbankan Syariah tingkat Jawa Tengah dan DIY, dengan jumlah peserta sebanyak 44 guru. Bentuk pengabdian ini berupa training keuangan syariah yang diisi oleh para pemateri dari instansi yang sudah kompeten. Sebelum training dimulai dilakukan pre test dengan hasil nilai rata-rata tiap peserta sebesar 63,11 dan setelah training dilalukan post test didapat nilai rata-rata peserta sebesar 77,07. Berdasarkan Uji Beda (Paired Samples Test) dengan SPSS dapat diketahui bahsa nilai signifikansi (Sig. (2-tailed)) sebesar 0.000 kurang dari 0,05. Maka dapat disimpulkan bahwa terdapat perbedaan yang nyata kompetensi guru perbankan syariah sebelum dilakukan training dan sesudah dilaksanakan training keuangan syariah.
\end{abstract}

Kata kunci-keuangan syariah, kompetensi guru, SMK perbankan syariah

\section{PENDAHULUAN}

Pertumbuhan bisnis terutama dibidang industri keuangan saat ini terus mengalami peningkatan dan pertumbuhan. Hal tersebut dibuktikan semakin banyaknya bermunculan bentuk bentuk bisnis baru di bidang keuangan itu sendiri. Salah satu contohnya adalah mulai muncul dan berkembangnya industri keuangan syariah saat ini yang menjadi salah satu pilihan investasi bagi masyarakat selain bentuk investasi yang sudah ada sebelumnya (konvensional). Bahkan perkembangan lembaga keuangan syariah di dunia diprediksi mencapai 14\% pertahun (Kustin, 2015). Investasi dengan model syariah ini sekarang menjadi trend di masyakat sebagai salah satu pilihan investasi. Dari sisi pelaku bisnis juga terus mengembangkan produkproduknya untuk semakin menarik hati para masyarakat. Sehingga saat ini muncul berbagai macam lembaga-lembaga keuangan syariah seperti perbankan syariah, asuransi syariah, pegadaian syariah dan lain sebagainya. Bahkan hampir semua lembaga keuangan perbankan dan lembaga keuangan bukan bankpun telah memiliki unit-unit yang berbasis syariah. Namum yang menjadi fokus perhatian masyarakat saat ini masih terfokus di perbankan syariah (Kementerian Perencanaan Pembangunan Nasional, 2018; OJK, 2017).

Khusus di sektor perbankan syariah sendiri berdasarkan data dari OJK, hingga tahun 2019 di Indonesia telah beroperasi 14 Bank Umum Syariah (BUS) dan 20 Unit Usaha Syariah (UUS). Perbankan syariah pada posisi Juni 2018 menunjukkan pertumbuhan yang positif dan intermediasi yang membaik dengan peningkatan aset, pembiayaan yang disalurkan (PYD), dan 
dana pihak ketiga (DPK) yang lebih tinggi dibandingkan periode yang sama tahun sebelumnya. Kinerja bank syariah pada Juni 2018 secara umum membaik dibandingkan akhir tahun 2017 yang ditunjukkan oleh rasio keuangan utama, baik dari sisi likuiditas, efisiensi, rentabilitas, maupun permodalan, yang menunjukkan perbaikan. Berdasarkan laporan OJK per Juni 2018 pertumbuhan asset bank syariah mencapai 13, 09\% yang mana pertumbuhan tersebut lebih besar daripada pertumbuhan bank konvensional yang hanya 9, $1 \%$. Pertumbuhan Pembiayaan Yang Disalurkan (PYD) mencapai 11, 25\% dan Pertumbuhan Dana Pihak Ketiga (DPK) sebesar 14, 58\%. Namun pertumbuhan tersebut dirasa kurang maksimal mengingat market share bank syariah masih 5, 70\% yang mana dianggap masih sangat kecil (OJK, 2017; Gunawan \& dkk, 2019).

Pertumbuhan industri keuangan syariah khususnya di sektor perbankan syariah tersebut juga direspon positif oleh dunia pendidikan baik perguruan tinggi (PT) maupun pendidikan sekolah menengah atas maupun kejuruan (SMA/SMK). Hal tersebut ditunjukkan dengan masuknya mata kuliah maupun pogram studi baik di PT maupun Di SMA/SMA. Terkhusus di SMK juga sudah mulai mengembangkan dan membuka program keahlian perbankan syariah sebagai upaya merespon pasar akan kebutuhan SDM yang kompeten untuk menunjang industri perbankan syariah. Namun Link and match sumber daya insani (SDI) di industri keuangan syariah belum mumpuni. Masih banyak para pelamar kerja ataupun tenaga kerja yang belum memahami secara mendalam perbankan syariah (https://www.republika.co.id, 2016). Penelitian menunjukkan bahwa mereka yang mengambil kursus tidak lebih melek finansial daripada mereka yang tidak. Sehingga menimbulkan pertanyaan serius tentang efektivitas jangka panjang dari pendidikan keuangan sekolah menengah (Lewis \& Klein, 2009).

Kehadiran program keahlian perbankan syariah di tingkat SMK masih menemui banyak kendala, diantaranya infrastruktur/fasilitas penunjang pendidikan seperti laboratium perbankan syariah yang mana belum semua sekolah memiliki karena mengingat program keahlian tersebut masih baru. Kendala yang lainnya adalah masih kurangnya guru yang memiliki kompetensi perbankan syariah sebagai pengajarnya karena belum tersedianya prodi keguruan perbankan syariah di tingkat perguruan tinggi. Sehingga di lapangan banyak guru-guru yang mengajar di program kehlian perbankan syariah adalah dari guru kompetensi lain seperti akuntansi maupun ekonomi (M \& Wahyu, 2017). Padahal kompetensi guru yang sesuai dengan program kompetensi perbankan syariah sangat dibutuhkan untuk menunjang dalam proses pembelajaran sehingga output/lulusan benar-benar menguasai kompetensi perbankan syariah sehingga bisa memenuhi kebutuhan pasar tenaga kerja lembaga keuangan syariah.

Kompetensi seorang guru merupakan sesuatu yang penting dalam proses pendidikan. Seorang guru dituntut untuk memiliki kompetensi yang layak sesuai dengan bidang ajarnya masing-masing guna mencetak anak-anak bangsa yang berkompeten dan memiliki daya saing dan dunia kerja. Berdasarkan Undang-undang Nomor 14 Tahun 2005 tentang Guru dan Dosen pada pasal 10 ayat (1) menyatakan bahwa "Kompetensi guru sebagaimana dimaksud dalam Pasal 8 meliputi kompetensi pedagogik, kompetensi kepribadian, kompetensi sosial, dan kompetensi profesional yang diperoleh melalui pendidikan profesi".

Salah satu kompetensi yang cukup penting adalah terkait dengan kompetensi profesional seorang guru. Kompetensi profesional merupakan penguasaan materi pembelajaran secara luas dan mendalam, yang mencakup penguasaan materi kurikulum mata pelajaran di sekolah dan substansi keilmuan yang menaungi materinya, serta penguasaan terhadap struktur dan metodologi keilmuannya. Sehingga seorang guru harus benar-benar menguasa materimateri yang diajarkan kepada peserta didiknya. Sehingga akan menghasilkan output atau lulusan yang benar-benar menguasi atau ahli sesuai dengan kompetensi yang di dalami oleh masing-masing siswa. Peran guru profesional dalam proses pembelajaran sangat penting sebagai kunci keberhasilan belajar siswa. Guru profesional adalah guru yang kompeten membangun proses pembelajaran yang baik sehingga dapat menghasilkan pendidikan yang berkualitas (Nursaidah, 2016).

Penjelasan tentang kompetensi guru tersebut, salah satu hal yang perlu mendapat perhatian adalah tentang kompetensi guru-guru pada program keahlian perbankan syariah di 
Sekolah Menengah Kejuruan (SMK). Maka, salah satu upaya untuk meningkatkan kompetensi tentang keuangan syariah tersebut adalah dengan cara memberikan pendampingan dan pelatihan tentang keuangan syariah kepada guru-guru pengampu di program keahlian perbankan syariah. Peningkatkan kompetensi sumber daya manusia terbukti efektif melalui motivasi, pelatihan dan pengembangan kerja, kompensasi, dan promosi (Restinasari, 2018; Khasan, Mulyono, \& Feriady, 2018; Onasis, Listihana, \& Aquino, 2017). Metode pembelajaran yang dapat meningkatkan inisiatif, kreatifitas, dan pengalaman peserta didik salah satunya melalui metode pembelajaran yang berdasarkan kehidupan dilingkungannya (Fauziyah, Kurjono, \& Disman, 2019). Karena pengalaman dengan instrumen keuangan berdampak lebih banyak dalam pengetahuan keuangan (Peng, Bartholomae, Fox, \& Cravener, 2007). Dalam meningkatkan literasi keuangan beberapa metode yang sering digunakan adalah games, role playing, ceramah, kunjungan ke lembaga keuangan dan pelatihan langsung dari lembaga keuangan dan akademisi terpercaya (Dhany, 2018; Walstad et al., 2010; Opletalova, 2015; Dewi \& Safaah, 2018).

Pada dasarnya pelatihan tentang keuangan syariah ini harus dilakukan kepada seluruh guru-guru pengampu mata pelajaran ekonomi di seluruh Indonesia atau yang terhimpun di Musyawarah Guru Mata Pelajaran (MGMP) Perbankan Syariah. Tetapi, melihat cukup banyaknya seluruh guru pengampu program keahlian perbankan syariah seluruh Indonesia, maka bisa dilakukan secara bertahap dan menyeluruh. Sehingga dalam pengabdian ini, akan di fokuskan pada Musyawarah Guru Mata Pelajaran Perbankan Syariah (MGMP-PS) Jawa Tengah dan DIY. Dengan meningkatnya wawasan dan literasi keuangan syariah bagi guru-guru perbankan syariah di tingkat SMK harapan besarnya mampu meningkatkan pertumbuhan industri keuangan syaraih di Indonesia.

\section{METODE}

Kegiatan pengabdian ini ditujukan kepada para guru-guru yang mengampu kompetensi keahlian perbankan syariah di SMK di wilayah Jawa Tengah dan DIY. Model pemecahan masalah yang diterapkan oleh tim pengabdian kepada masyarakat adalah pelatihan tentang keuangan syariah dari para praktisi perbankan syariah dan akademisi dari perguruan tinggi yang diharapkan dapat menghasilkan peningkatan kompetensi keilmuan guru-guru perbankan syariah. Guru pengampu kompetensi keahlian perbankan syariah di SMK diharapkan mampu memahami dan memiliki pengetahuan tentang keuangan syariah secara komprehensif sehingga dalam proses pembelajaran dapat berjalan secara baik sehingga mampu menghasilkan ouput/lulusan yang benar-benar berkompeten.

Identifikasi masalah:

1. Masih rendahnya kompetensi guruguru perbankan syariah di SMK

2. Belum adanya forum untuk pengembangan kompetensi keuangan syariah bagi MGMP Perbankan Syariah
Hasil yang diperoleh:

1. Guru mendapatkan wawasan perkembangan industri keuangan syariah

2. Guru memiliki pengetahuan dan meningkatnya kompetensi keuangan syariah

3. Hasil output/lulusan yang memiliki kompetensi perbankan syariah
Proses pelatihan:

1. Memeberikan wawasan perkembangan industri perbankan saat ini

2. Memberikan pelatihan materi baik teori, konsep dan praktik produk-produk perbankan syariah

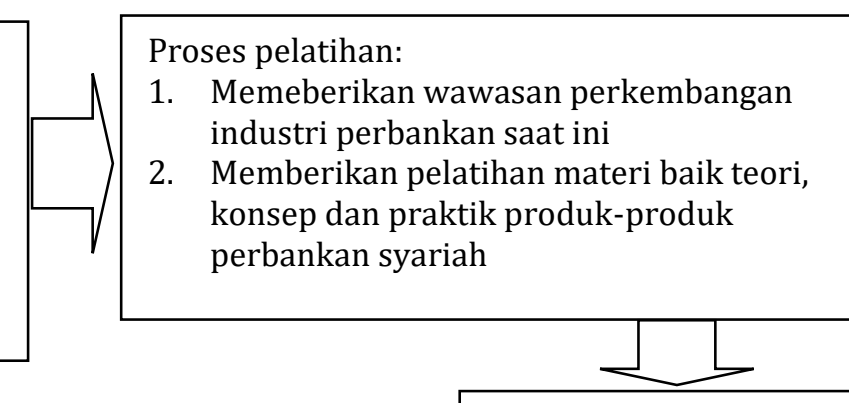

Prosespendampingan:

1. Pendampingan penyusunan modul keuangan syariah

2. Pendampingan praktik pengajaran di laboratorium perbankan syariah

Gambar 1. Bagan kerangka pemecahan masalah 
Realisasi pelaksanaan model pengabdian ini adalah memberikan wawasan tentang perkembangan industri perbankan syariah di Indonesia saat ini dan bentuk-bentuk aplikasi dan pengembangan produk-produk perbankan syariah. Hal ini sebagai materi awal yang diberikan kepada guru-guru pengampu perbankan syariah sehingga keilmuan tentang perbankan syariah bertambah. Hal ini juga sebagai upaya dari respon dari perkembangan keuangan syariah saat ini yang menuntut dunia pendidikan juga bisa ikut mengikuti perkembangan. Sehingga diharapkan guru-guru akan lebih memahami dan menguasai isu-isu terkini dan perkembangan perbankan syariah yang nantinya akan disampaikan kepada siswa.

Selanjutnya guru akan diberikan materi tentang akuntansi keuangan syariah yang terbaru mengungat standar akuntansi syariah juga mengalami perubahan dan perkembangan. Sehingga diharapkan guru-guru juga menguasi bagaimana laporan keuangan di lembaga keuangan syariah yang tentunya sangat berbeda dengan laporan keuangan yang ada di lembaga keuangan konvensional termasuk perbankan konvensional. Hal ini juga untuk mendukung dalam penyampaian materi akuntansi perbankan syariah dan praktik akuntansi perbankan syariah yang ada di kompetensi keahlian perbankan syariah di SMK.

\section{HASIL DAN PEMBAHASAN}

Pengabdian dilaksanakan sesuai dengan rancangan sebagaimana yang telah diuraikan pada metode pengabdian. Sebelum dilaksanakan pelatihan kepada mitra pengabdian yaitu MGMP Perbankan Syariah Jawa Tengah dan DIY, maka dilakukan tahap identifikasi awal. Proses ini dilakukan dengan koordinasi dan diskusi dengan pihak mitra khususnya pengurus MGMP Perbankan Syariah Jawa Tengah dan DIY. Tujuan dilakukannya identifikasi awal adalah bertujuan untuk mengetahui secara persis permasalahan-permasalahan yang dihadapi oleh guru-guru perbankan syariah kaitannya dalam aktivitas pembelajaran dan pendidikan di sekolah-sekolah.

Kegiatan ini telah berhasil dilaksanakan dengan adanya pertemuan untuk melakukan diskusi antara tim pengabdian dengan perwakilan dari MGMP Perbankan Syariah. Kegiatan diskusi dan identifikasi masalah ini dilaksanakan pada tangga 3 Mei 2019.

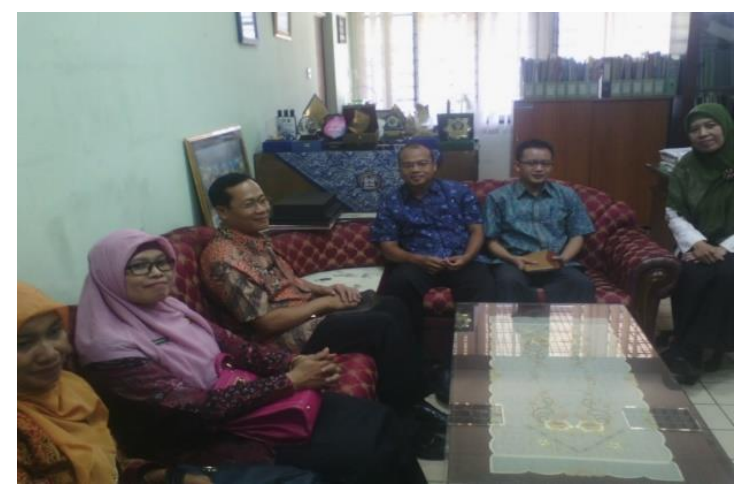

Gambar 2. Koordinasi dengan pengurus MGMP Perbankan Syariah Jawa Tengah dan DIY

Dari hasil diskusi tersebut dapat disimpulkan beberapa hal. Pertama, masih rendahnya kompetensi guru-guru perbankan syariah di SMK-SMK yang ada saat ini. Hal itu disebabkan karena sebagian besar pengajar kompetensi perbankan syariah memiliki background pendidikan yang tidak di bidang yang berkaitan dengan perbankan syariah. Mayoritas guru-guru pengajar perbankan syariah berasal dari background pendidikan seperti guru akuntansi dan guru ekonomi, sehingga kompetensi mereka di bidang perbankan syariah masih terbatas. Dan sebagian kecil guru yang memang memiliki background pendidikan di bidang perbankan/ekonomi/keuangan syariah. Namun kendala yang dihadapai adalah guru tersebut tidak memiliki background di bidang pendidikan keguruan.

Kedua, masalah lain yang dihadapi oleh MGMP Perbankan Syariah adalah belum adanya wadah untuk meningkatkan kompetensi mereka di bidang keuangan/perbankan syariah. Sekaligus ini yang menjadi latar belakang dibentuknya MGMP Perbankan Syariah. Dengan 
harapan ini menjadi wadah bagi guru-guru untuk saling berbagi informasi dan diskusi sebagai upaya kecil untuk meningkatkan kompetensi mereka. Sehingga dari hasil identifikasi masalah tersebut menjadikan semakin kuatnya alasan dilakukannya pengabdian masyarakat ini sebagai upaya peningkatan kompetensi guru-guru perbankan syariah.

Setelah dilaksanakan pemetaan permasalahan yang terjadi pada mitra pengabdian maka kemudian dilaksanakan pengabdian kepada masyarakat berupa training keuangan syariah bagi guru-guru perbankan syariah. Sesuai dengan hasil diskusi dengan pihak mitra maka pelaksanaan pengabdian dilaksanakan pada hari Selasa-Rabu, 10-11 September 2019 bertempat di Fakultas Ekonomi Universitas Negeri Semarang. Dalam proses pelaksanaan kegiatan ini dihadiri oleh 44 guru perwakilan dari masing-masing sekolah yang tergabung dalam MGMP Perbankan Syariah se- Jawa Tengah dan DIY.

Untuk memaksimalkan kegiatan pengabdian ini maka tim pengabdian juga mengajak kerjasama Jurusan Pendidikan Ekonomi FE UNNES, Otoritas Jasa Keuangan (OJK), BPD Jateng Syariah dan Bursa Efek Indonesia Kantor Semarang. Sehingga dengan adanya kerjasama tersebut materi yang diberikan kepada guru-guru perbankan syariah lebih komprehensif. Kegiatan pengabdian ini dilaksanakan selama dua hari dengan tujuan untuk mendapatkan hasil yang maksimal, yaitu meningkatnya kompetensi keahlian bagi guru di bidang ekonomi dan keuangan syariah.

Bagi Otoritas Jasa Keuangan dan Lembaga Keuangan Islam lainnya kegiatan ini merupakan bagian dari gerakan literasi keuangan syariah. Dengan ini ditargetkan dapat meningkatkan angka literasi masyarakat Indonesia akan produk keuangan syariah yang nantinya dapat mendorong pemanfaatan produk dan jasa keuangan sesuai kebutuhan masyarakat muslim pada khususnya dan masyarakat Indonesia dan dunia pada umumnya (Hani \& Indri, 2019).

Kegiatan hari pertama dilaksanakan pada hari Selasa, 10 September 2019 dengan rincian kegiatan sebagai berikut; pembukaan acara dilaksanakan di Aula Fakultas Ekonomi UNNES dengan diawali registrasi dari para peserta yaitu guru-guru perbankan syariah se-Jawa Tengah dan DIY serta dihadiri pula perwakilan dari mahasiswa yang diambilkan dari kelas mata kuliah Bank dan Lembaga Keuangan.

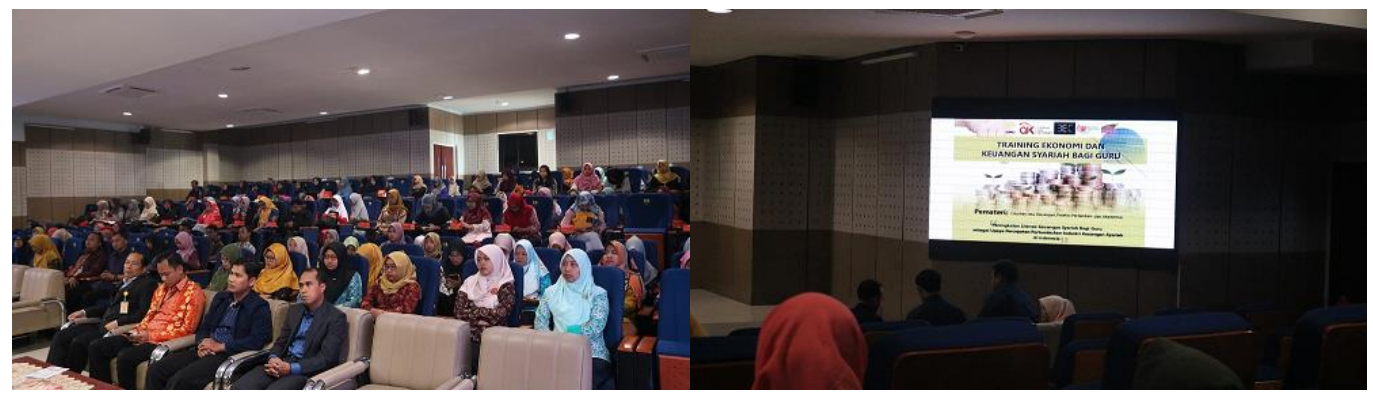

Gambar 3. Acara pembukaan training ekonomi dan keuangan syariah

Secara umum pelakasanaan pengabdian masyarakat ini dilakukan melalui pemberian materi dari para pemateri-pemateri yang telah disiapkan oleh tim pengabdian. Keseluruhan materi yang disampaikan dalam acara training ini terdiri dari enam materi yang di sampaikan dari beberapa pemateri yang berasal dari berbagai instansi seperti Otoritas Jasa Keuangan (OJK), Bank Jateng Syariah, UIN Walisongo Semarang, POLINES dan Masyarakat Ekonomi Syariah (MES).

Materi pertama disampaikan oleh Otoritas Jasa Keuangan (OJK) yang diwakili oleh Bapak Catur Surya Perwira selaku Divisi Edukasi dan Perlindungan Konsumen OJK Regional 3 Jawa Tengah dan DIY. Adapun materi yang disampaikan adalah tentang perkembangan dan regulasi perbankan syariah di Indonesia. Dalam materi ini disampaian gambaran secara umum perkembangan industri perbankan syariah di Indonesia yang cukup bagus. Namun perkembangan tersebut dirasa masih belum optimal dikarenakan salah satu kendalanya adalah masih rendahnya tingkat literasi keuangan syariah masyarakat. 


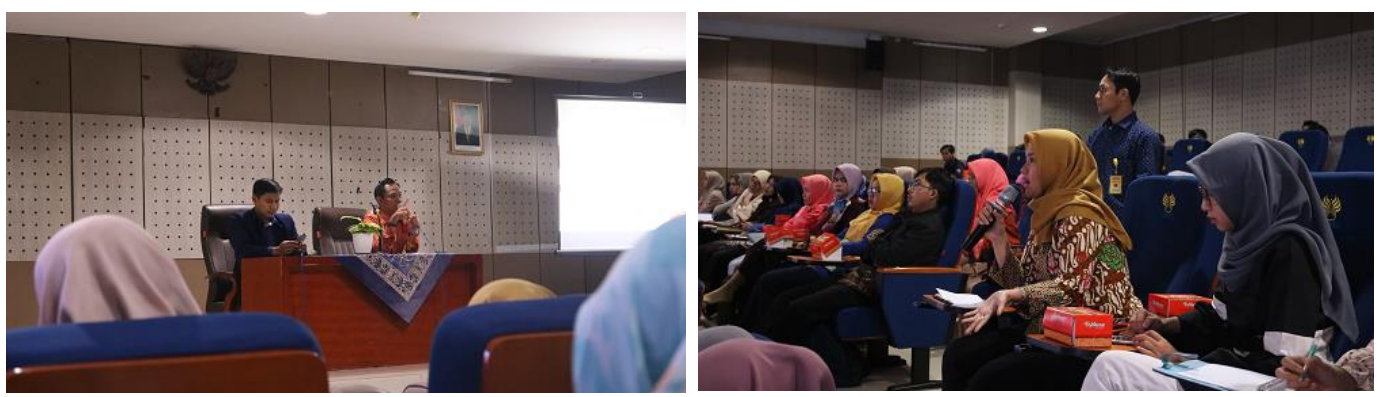

Gambar 4. Penyampaian mater 1 dari OJK dan sesi diskusi dengan peserta training

Setelah acara pembukaan dan penyampaian materi pertama, dilanjutkan dengan penampaian materi-materi selanjutnya yang mana dilaksanakan di kelas. Tujuannya adalah agar kegiatan training tersebut bisa berjalan lebih intensif. Adapun materi kedua dalan selanjutnya disampaikan oleh Prof. Dr. Abdul Ghofur, M.Ag dari UIN Walisongo Semarang dengan tema pengantar ekonomi islam. Dilanjutkan materi-materi selanjutnya disampaikan oleh Bapak Slamet Sulistyo selaku Wakil Kepala Divisi Syariah Bank Jateng dengan tema kegiatan dan inovasi produk bank syariah, dilanjutkan materi dari Bapak Nyata Nugraha, SE.,M.Si dari POLINES tentang akuntansi syariah, dilanjutkan Ibu Ririn Winarni dari OJK tentang asuransi dan lembaga keuangan mikro syariah, dan yang terakhir materi dari Bapak Fanny Rifqi El-Fuad dari IDX Semarang tentang pasar modal syariah.
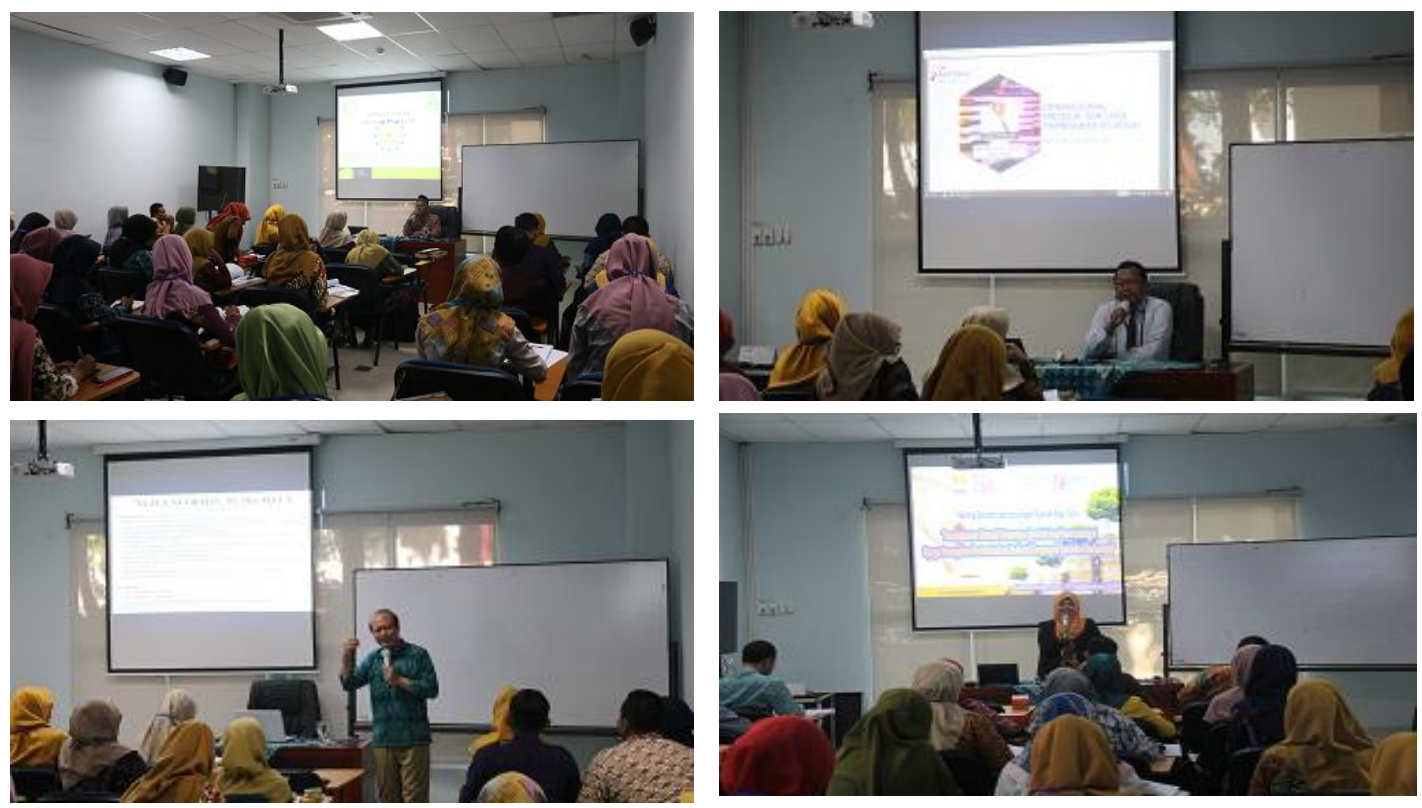

Gambar 5. Para pemateri menyampaikan materi di masing-masing sesi

Secara umum kegiatan pelakasanaan training ekonomi dan kuangan syariah tersebut telah berjalan dengan lancar. Hal tersebut ditandai dengan tertibnya acara sesuai dengan konsep yang telah dirancang oleh tim pengabdian. Selain itu juga ditandai dengan tingginya antusiasme peserta training dari pembukaan hingga selesainya acara. Di setiap sesi materi juga peserta menunjukan keaktivannya melaui pengajuan pertanyaan-pertanyaan serta diskusi yang terjadi di setiap sesi materi.

Dalam rangkaian acara tersebut dilakukan pre test dan post test kepada seluruh guruguru perbankan syariah yang merupakan peserta acara training tersebut. Tentunya ini memiliki tujuan untuk mengukur seberapa jauh pengaruh adanya training ini terhadap kompetensi guru perbankan syariah. Berdasarkan hasil pre test dan post test yang dilakukan selama pelaksanaan pelatihan keuangan syariah tersebut menunjukkan hasil yang positif. Dimana kompetensi tentang keuangan syariah guru-guru peserta pelatihan mengalami kenaikan setelah 
dilaksanakannya pelatihan. Hal ini manjadikan salah satu indikator keberhasilan dalam kegiatan pengabdian ini. Adapun tabel hasil pre test dan post test peserta training adalah sebagai berikut:

Tabel 1. Hasil pre test dan post test peserta training

\begin{tabular}{|c|c|c|c|}
\hline \multirow{2}{*}{ Guru Ke- } & \multirow{2}{*}{ Asal Sekolah } & \multicolumn{2}{|c|}{ Nilai } \\
\hline & & Pre Test & Post Test \\
\hline 1 & SMK 3 Jepara & 70 & 87 \\
\hline 2 & SMK Bhakti Nusantara Salatiga & 70 & 83 \\
\hline 3 & SMK Diponegoro Salatiga & 63 & 73 \\
\hline 4 & SMK Kartika Nusantara Semarang & 37 & 47 \\
\hline 5 & SMK Miftahul Huda Limbangan Kendal & 63 & 73 \\
\hline 6 & SMK Muhammadiyah 2 Boja & 63 & 77 \\
\hline 7 & SMK YAPPI Wonosari & 70 & 80 \\
\hline 8 & SMK YAPPI Wonosari & 53 & 63 \\
\hline 9 & SMK Diponegoro Banyuputih, Batang & 70 & 77 \\
\hline 10 & SMK Muhammadiyah 04 Sukorejo & 40 & 73 \\
\hline 11 & SMK Muhammadiyah 2 Muntilan & 53 & 93 \\
\hline 12 & SMK Muhammadiyah Dukun & 77 & 90 \\
\hline 13 & SMK Muhammadiyah 3 Purbalingga & 63 & 70 \\
\hline 14 & SMK Komputama Majenang & 60 & 67 \\
\hline 15 & SMK N 1 Batang & 77 & 83 \\
\hline 16 & SMK N 4 Kendal & 67 & 83 \\
\hline 17 & SMK Islam Jepara & 63 & 70 \\
\hline 18 & SMK Muhammadiyah 04 Sukorejo & 70 & 80 \\
\hline 19 & SMK Muhammadiyah 3 Mayong Jepara & 67 & 80 \\
\hline 20 & SMK Muhammadiyah Somagede & 60 & 67 \\
\hline 21 & Smk Muh. 1 Ajibarang Banyumas & 67 & 73 \\
\hline 22 & SMK Subbanul Waton Secang & 73 & 87 \\
\hline 23 & SMK Negeri 1 Kendal & 60 & 73 \\
\hline 24 & SMK Muhammadiyah Kesesi Pekalongan & 63 & 70 \\
\hline 25 & SMK Teknosa Surakarta & 67 & 77 \\
\hline 26 & SMK Muhammadiyah Kesesi Pekalongan & 63 & 73 \\
\hline 27 & SMK Islamic Centre Baiturrahman Semarang & 70 & 77 \\
\hline 28 & SMK Bina Nusa Slawi & 53 & 83 \\
\hline 29 & SMK Islam Roudlotus Saidiyyah & 70 & 77 \\
\hline 30 & SMK Manggala Tama Binangun & 40 & 77 \\
\hline 31 & SMK Islam Randudongkal & 63 & 70 \\
\hline 32 & SMK Islam Nusantara Comal & 73 & 80 \\
\hline 33 & SMK Komputama Jeruklegi & 33 & 77 \\
\hline 34 & SMK N 1 Bantul & 73 & 80 \\
\hline 35 & SMK Islam Terpadu Al-Huda Wonogiri & 73 & 80 \\
\hline 36 & SMK N 1 Batang & 67 & 77 \\
\hline 37 & SMK Darululum Sidareja & 43 & 77 \\
\hline 38 & SMK Batik Miftahul Ulum Batang & 77 & 87 \\
\hline 39 & SMK NU Hasyim As'ari Tarub & 73 & 80 \\
\hline
\end{tabular}




\begin{tabular}{llll}
\hline 40 & SMK Walisongo Pecangaan & 63 & 80 \\
\hline 41 & SMK Ma'arif NU 1 Semarang & 73 & 80 \\
\hline 42 & SMK Negeri 4 Klaten & 47 & 70 \\
\hline 43 & Ketua MGMP-Perbankan Syariah & 70 & 83 \\
\hline 44 & SMK N 1 Kudus & 67 & 87 \\
\hline
\end{tabular}

Berdasarkan nilai hasil pre test dan post test tersebut dilakukan pengolahan data Uji Beda dengan menggunakan SPSS. Tujuannya adalah untuk mengukur tingkat signifikansi kompetensi guru perbankan syariah setelah dilakukannya training keuangan syariah tersebut. Adapun hasil olah data dapat dilihat sebagai berikut:

Tabel 2. Paired Samples Statistics

\begin{tabular}{llrrrr}
\hline & & Mean & N & Std. Deviation & Std. Error Mean \\
\hline Pair 1 & pretest & 63.11 & 44 & 11.094 & 1.673 \\
& postest & 77.07 & 44 & 7.957 & 1.200 \\
\hline
\end{tabular}

Berdasarkan tabel Paired Samples Statistics tersebut dapat diketahui bahwa mean atau nilai rata-rata dari dari masing-masing variabel. Nilai rata-rata dari pre test adalah sebesar 63.11, sedangkan nilai rata-rata post test adalah sebesar 77.07. Maka dapat kita simpulkan bahwa rata-rata dari seluruh guru perbankan syariah yang menjadi peserta training ini mengalami kenaikan kompetensi mereka. Adapun signifikansi dari kenaikan kompetensi tersebut dapat dilihat pada tabel berikut ini:

Tabel 3. Paired Samples Test

\begin{tabular}{|c|c|c|c|c|c|c|c|c|c|}
\hline & & \multicolumn{5}{|c|}{ Paired Differences } & \multirow[b]{3}{*}{$\mathrm{t}$} & \multirow[b]{3}{*}{$\mathrm{df}$} & \multirow{3}{*}{$\begin{array}{l}\text { Sig. (2- } \\
\text { tailed) }\end{array}$} \\
\hline & & \multirow[b]{2}{*}{ Mean } & \multirow{2}{*}{$\begin{array}{c}\text { Std. } \\
\text { Deviation }\end{array}$} & \multirow{2}{*}{$\begin{array}{l}\text { Std. } \\
\text { Error } \\
\text { Mean }\end{array}$} & \multicolumn{2}{|c|}{$\begin{array}{l}\text { 95\% Confidence } \\
\text { Interval of the } \\
\text { Difference }\end{array}$} & & & \\
\hline & & & & & Lower & Upper & & & \\
\hline Pair 1 & $\begin{array}{l}\text { pretest } \\
- \\
\text { postest }\end{array}$ & 13.955 & 9.930 & 1.497 & -16.974 & -10.936 & 9.322 & 43 & .000 \\
\hline
\end{tabular}

Dari tabel Paired Samples Test dapat dilihat bahwa nilai signifikansi (Sig. (2-tailed)) dari hasil uji beda kedua variabel tersbut adalah sebesar 0.000. Sesuai dengan kaidah dasar pengambilan keputusan statisitik maka jika nila siginifikansi (Sig. (2-tailed)) kurang dari 0,05, maka terdapat perbedaan yang signifikan. Begitu jika nilai Siginifikansi (Sig. (2-tailed)) lebih besar dari 0,05, maka tidak terdapat perbedaan yang signifikan (Imam, 2011). Berdasarkan table paired sample test tersebut diketahui bahwa nilai signifikansinya adalah sebesar 0,000 kecil dari 0.05. Maka dapat disimpulkan bahwa terdapat perbedaan yang siginifikan kompetensi guru perbankan syariah sebelum dilakukan training dan sesudah dilaksanakan training keuangan syarian ini.

\section{KESIMPULAN}

Kegiatan pengabdian kepada masyarakat tentang peningkatan literasi keuangan syariah bagi guru-guru perbankan syariah berjalan dengan lancar. Peserta dalam acara ini berjumlah 44 guru perwakilan dari masing-masing sekolah yang memiliki kompetensi keahlian perbankan syariah atau yang tergabung dalam wadah Musyawarah Guru Mata Pelajaran Perbankan Syariah (MGMP-Perbankan Syariah) Jateng dan DIY. Bentuk kegiatan adalah pemaparan dari para pemateri yang disediakan oleh tim pengabdian yang bekerjasama dengan beberapa lembaga seperti OJK, Bank Jateng Syariah, IDX dan akademisi (UIN Walisongo dan POLINES). Bentuk kegiatan ini berupa penyampaian materi serta sesi tanya jawab dan diskusi antara pemateri dengan peserta. Dari hasil pengabdian masyarakat tersbut dapat diketahui adanya peningkatan 
literasi keuangan syariah para peserta pelatihan. Peningkatan tersebut dapat diketahui dari adanya pre test dan post test yang telah dilakukan tim pengabdian masyarakat kepada peserta training. Dengan begitu pengabdian ini benar-benar telah memberikan manfaat kepada mitra terutama dalam peningkatan kompetensi mereka dibidang ekonomi dan keuangan syariah.

\section{UCAPAN TERIMA KASIH}

Penulis mengucapkan terima kasih kepada Fakultas Ekonomi Universitas Negeri Semarang yang telah memberi dukungan financial terhadap pengabdian ini.

\section{DAFTAR PUSTAKA}

Dewi, I. K., \& Safaah, R. H. (2018). Strategi Bank Syariah dalam Meningkatkan Literasi Keuangan Syariah pada Masyarakat (Studi Kasus pada BPRS Madina Mandiri Sejahtera). Jurnal Ekonomi Syrariah Indonesia, 8(2).

Dhany, E. S. (2018). Pendidikan Literasi Keuangan Melalui Program Kemitraan Dengan Bank Untuk Mengurangi Perilaku Konsumtif Pada Mahasiswa. Jurnal Pendidikan Ilmu Sosial, 28(1).

Fauziyah, A., Kurjono, \& Disman. (2019). Pengaruh Penggunaan Metode Pembelajaran Group Investigation Terhadap Literasi Keuangan Dengan Moderator Kecerdasan Emosional. Jurnal Ilmu Manajemen Dan Bisnis, 10(1).

Gunawan, S. U., \& dkk. (2019). Laporan Perkembangan Keuangan Syariah Indonesia 2018. Jakarta. Retrieved from https://www.ojk.go.id/

Hani, M. P. S., \& Indri, Y. (2019). Efektivitas Gerakan Literasi Keuangan Syariah Dalam Mengedukasi Masyarakat Memahami Produk Keuangan Syariah. Banque Syar'i: Jurnal Ilmiah Perbankan Syariah, 5(1).

https://www.republika.co.id. (2016). Perbankan Syariah Butuh Standar Kompetensi Khusus. Retrieved January 28, 2020, from https://www.republika.co.id/berita/koran/ekonomikoran/16/12/20/oih4w620-perbankan-syariah-butuh-standar-kompetensi-khusus

Imam, G. (2011). Aplikasi Analisis Multivariate Dengan Program SPSS. Semarang, Indonesia: Badan Penerbit Universitas Diponegoro.

Kementerian Perencanaan Pembangunan Nasional. (2018). Masterplan Ekonomi Syariah Indonesia 2019-2024. Jakarta. Retrieved from https://ubico.id/

Khasan, S., Mulyono, K. B., \& Feriady, M. (2018). Pengembangan Kualitas Pembelajaran Prakarya Dan Kewirausahaan Bagi Guru Smk Dan Sma Jawa Tengah. In Seminar Nasional Kolaborasi Pengabdian Pada Masyarakat (p. Vol 1 No 1 (2018): Proceeding SNKPPM 2018). Semarang. Retrieved from https://proceeding.unnes.ac.id/index.php/snkppm

Kustin, B. (2015). Islamic (Micro) Finance : Culture, Context, Promise, Challenges. Bill \& Melinda Gates Foundation. Retrieved from https://www.findevgateway.org/

Lewis, M., \& Klein, L. S. (2009). The Impact of Financial Literacy Education on Subsequent Financial Behavior. Journal of Financial Counseling and Planning, 20(1).

M, A., \& Wahyu, A. H. (2017). Urgensi Literasi Keuangan Syariah pada Pendidikan Dasar. MIYAH: Jurnal Studi Islam, 13(1).

Nursaidah. (2016). Modul Paket Keahlian Perbankan Syariah Sekolah Menengah Kejuruan (SMK). Jakarta, Indonesia: Pusat Pengembangan dan Pemberdayaan Pendidik dan Tenaga Kependidikan Bisnis dan Pariwisata, Direktorat Jenderal Pendidik dan Tenaga Kependidikan.

OJK. (2017). Roadmap Pengembangan Keuangan Syariah Indonesia 2017-2019. Jakarta. Retrieved from https://www.ojk.go.id/id/k

Onasis, D., Listihana, W. D., \& Aquino, A. (2017). Pelatihan Penyusunan Dan Penyajian Laporan Keuangan Untuk Usaha Mikro, Kecil, Dan Menengah Yang Berbasis Standar Akuntansi Keuangan (Sak) Entitas Tanpa Akuntabilitas Publik (Etap) Di Desa Muara Jalai Kecamatan Kampar Utara Kabupaten Kampar. Dinamisia : Jurnal Pengabdian Kepada Masyarakat, 1(1), 15-22. https://doi.org/https://doi.org/10.31849/dinamisia.v1i1.279

Opletalova, A. (2015). Financial education and financial literacy in the Czech education system. Procedia Social and Behavioral Sciences, 171, 1176 - 1184. 
Peng, T.-C. M., Bartholomae, S., Fox, J. J., \& Cravener, G. (2007). The Impact of Personal Finance Education Delivered in High School and College Courses. J Fam Econ Iss, 28, 265-284. https://doi.org/DOI 10.1007/s10834-007-9058-7

Restinasari, L. (2018). Strategi Peningkatan Kompetensi Sumber Daya Manusia Melalui Pelatihan Dasar Perbankan (Studi Kasus di PT. Bank Syariah Mandiri Cabang Cipulir). Universitas Muhammadiyah Jakarta. Retrieved from http://repository.umj.ac.id/jspui/

Walstad et al. (2010). The Effects of Financial Education on the Financial Knowledge of High School Students. The Journal of Consumer Affairs, 44(2). 